\title{
Islamic Religious Value in Traditional Ceremony of Begalan Banyumasan as Educational Character for Student at Senior High Schools In Central Java
}

\author{
Kundharu Saddhono, , , Alva Kuniawan, \\ ${ }^{a}$ Graduate Program, Universitas Sebelas Maret. \\ ${ }^{b}$ Graduate Program, Universitas Sebelas Maret. \\ *Corresponding author: kundharu.uns@gmail.com

\section{Article history} \\ Received: 10/10/2016 \\ Received in revised form: 09/03/2017 \\ Accepted: 14/03/2017
}

\section{Abstract}

The purpose of this paper is to describe: (1) the form of Begalan traditional ceremony, (2) the meaning contained in brenang kepang, (3) the religious values of Islam in a Begalan traditional ceremony. This research is descriptive qualitative. The data collection techniques in this study are observation, interview, and reviewing documents and archives. The object of this study is a religious value in a traditional ceremony of Begalan Banyumasan. The data analysis technique in this research is qualitative descriptive analysis and interactive. Begalan Banyumasan traditional ceremony is a form of ritual to get rid of negative things. From the order of performance time, speech, and tools brought in Begalan have meaning and religious value. Therefore, the traditional ceremony of Begalan Banyumas is very suitable as a source of educational character in schools.

Keywords: Islam; religious value; Begalan; Bayumasan; character building 


\subsection{INTRODUCTION}

Begalan is a traditional performance in a series of marriage ceremony in Banyumas residence. This tradition began when the groom and his family entered the yard of the bride's house. This tradition is carried out when the groom is the eldest son of a family (Herusatoto, 2008: 235). The interesting part of Begalan traditional ceremony isthe dialogue between the robbed victims (dibegal) and the robber (pembegal). The dialogues usually contain criticism and advice for the bride and the groom that delivered in a funny and humorous style. Begalan is a combination of dance and the art of speech or comedy with musical accompaniment.

Begalan ceremony is a combination of dance with "verbal speech" as part of a wedding ceremony. That is when the groom's family entered the yard of the bride's house (Suwito, 2008: 5 ). The tools carried as the luggage are kitchen equipment. Each the luggage especially kitchen tool has a symbolic meaning according to the philosophy of Java, especially Banyumasan. The equipment takenwas: ilir(fan), ian, cething, kukusan, saringanampas, tampah, sorokan, centhong, siwur, irus, kendhikarowangkring, and others.

The dialogue in Begalan ceremony contains some advices to the bride and the groom in marriage. Begalan often uses fresh jokes related to the relationship between men and women. In Banyumas community philosophy, the thing that being robbed is not his wealth but bajang sawane, the blessing of the bride's parents. There were two dancers (one male and one pancer brother of the groom), the one is carrying the kitchen equipment, while the others served as the robber. The robber usually carries a wooden sword. The clothes of the player is quite simple, they are generally dressed in Java style. Dialogue delivered from both performances is in the form of a language symbol that translates from the names of the types of goods carried. Usually, after the show, the kitchen equipment brought was given to the audience as a door prize (Suwito, 2008: 6).

Begalan traditional ceremony is a unique tradition in marriage. Begalan means there can be a robbing in marriage. The similar unique tradition is I Serahen Ku Guru in the Ngerje marriage ceremony (Selian, 2007), this tradition is a tradition of giving advice by the petua or tengku. The advices contain the main points of belief and responsibility of husband and wife. It also explains about how to live in the society along with examples and the proverb of Gayo. The difference between I Serahen Ku Guru and Begalan is in the implementation time and the delivery of the advice. Begalan give the advice by explaining the symbols of household furniture.

Begalan tradition in Banyumas at least three meanings contained in it, namely the textual meaning, contextual meaning and symbolic meaning. The textual meaning of Begalan ritual is in the form of the provision to the bride about the household. The contextual meaning of Begalan ritual is asking for the safety in life.

The concept of the values of character establishment is very diverse. The value of forming a complete character is proposed by the Curriculum Center of the Education Development and Culture and National Character. The character pillar value according to the Center for Curriculum, Research and the Ministry of Education was formulated as much as eighteen items of value that should be developed to shape the character of the students in Indonesia (Wibowo, 2013: 15-16). The purpose of education character by Suhartono (2008: 103) is improving the quality of education in schools and the students' achievement, students' noble establishment, integrated and balanced according to the standards competency. Those values are (1) religious, (2) honest, (3) tolerance, (4) discipline, (5) hard work, (6) creative, (7) independent, (8) democratic, (9) curiosity, (10) the spirit of nationalism, (11) patriotism, (12) the achievements, (13) friendly or communicative, (14) pacifist, (15) improving the reading habits, (16) environment caring, (17) social caring, and (18) responsibility. 


\subsection{RESEARCH METHODOLOGY}

The study about the equipment of the brenang kepang in Begalan Banyumasan traditional ceremonies carried out in Banyumas. This study was a qualitative research. The type of the study was qualitative descriptive. That is by performing a research of the objects finding and interpret the relationship of the various elements in it (Sutopo, 2006: 86). The data collection techniques in this study were observation, interview, and reviewing documents and archives (content analysis). The data analysis technique in this research is qualitative descriptive analysis and interactive, the data analysis focuses on the meaning, descriptions, and placement of data on the each context (Sutopo, 2006: 107).

\subsection{THE FORM OF BEGALAN}

The results showed the form of brenang kepang developed in the community is divided into two types: The ancient brenang kepang and modern brenang kepang. The ancient brenang kepang contained twelve kinds of kitchen equipment that made from natural materials. The equipment of ancient brenang kepang were ian, ilir, embatan, kukusan, cirimuthu, cething, centhong, tampah, siwur, irus, kendhil pratala, kekeb, sorok, sapulidi, danpadi. The form of brenag kepang developed in the Banyumas society was mostly using the ancient brenangkepang. The kitchen equipment used in modern or contemporary brenangkepangwas not made from the natural materials and some of the equipment are being replaced without reduced its function.

The modern or contemporary brenang kepang was the form of brenang kepang that consist of kitchen equipment but the material was not from the nature, like bamboo. Some of the equipment was replaced with the modern one, such as: cething was replaced with magic jar, siwur was replaced with plastic water dipper, sorok replaced with stainless sorok, and another kitchen equipment made of plastic. Thus, not all of the equipment carried in modern brenang kepang is made of natural materials.

The reason of using the modern kitchen equipment were: (1) the house owner thought that it is more efficient, it is easy to get those things; (2) the householder thought that the modern kitchen equipment can replaced the old kitchen equipment because it has the same function; (3) Some people who held Begalan Banyumasan was having difficulties to find the kitchen equipment in ancient brenang kepang. The form of brenang kepang usually provided and assembled by the Begalan Banyumasan performances. So, they can know about the equipment that being used and arranged to explain it to the audience.

There were some of the house owners that held Begalan Banyumasan ceremony provided ancient brenangkepang. It was easier for the performances of Begalan Banyumasan because they did not need to carry and arrange the kitchen equipment used in brenangkepang. The performances of Begalan Banyumasan just recited the meaning of all the symbols in the form of kitchen equipment and gave some advices on married life provision (Herusatoto, 2008: 239).The second form of brenang kepang is modern or contemporary brenang kepang. The forms has been modified and developed in some of the kitchen equipmnet used. The modern or contemporary brenang kepang was the form of brenang kepang that consist of kitchen equipment but the material was not from the nature.

Begalan Banyumasan traditional ceremony was one of ritual to rid of the negative things from the brides (sukerta). This has been done by explaining the meanings conveyed through the symbolization of brenang kepang equipment. Thus were appropriate with the results of study by Sunarto (2013: 70-78) titled Leather Puppet in Javanese Ritual Ceremony. The results showed that the shadow puppet show can be used as a tool of ritual to get rid of negative things (larung sukerta) for someone.

A discussion of forms of performance art of Begalan outlines everything related to the performing arts of Begalan and attendance can be felt by the senses. Performing arts of Begalan time to adjust to Panggih wedding ceremony. If Panggih wedding ceremony held during the day, 
then Begalan staged during the day. But if Panggih wedding ceremony held the evening, then Begalan staged night. The time for the staging is not mandatory, but is highly dependent on the will of the responders or adjust the existing circumstances

Performing arts of Begalan starting from the entry of the bride or groom to the ceremony location, accompanied by his parents and guided by a bridal makeup artist. Normally execution took place in the front yard of the bride, accompanied by gendhing Kebogiro, escorted by two players Begalan complete with its brenang braid. Players Begalan swordbearer escorting the bride, while the players Begalan brenang kepang carrier escort the groom. Arriving at the place set up, the bride and groom sit accompanied by parents each bride.

After coming to a place prepared, groom sitting next to his parents, and the bride was accompanied by her parents sat in the sitting position facing each other to jointly witness the Begalan. Begalan performances staged in the middle so that both the bride and her parents all can clearly follow the show, so understand all the contents of the advice outlined by Begalan players.

Both interpreter robber then danced the piece Banyumasan dish. After serving Gendhing suwuk (stop), the players stopped dancing. Players who are in charge of carrying brenang kepang laying luggage. In this section, both players were in the show ring, but the new active players to one. The second player to act as if it has not entered into a staging arena. Players to one (messenger of the princess) then performed a monologue.

Performances further illustrate the groom's envoy trip, followed by the introduction between the two envoys. In this section two players to have started to actively interact with the player first. One of the players (usually carrier brenang braid) introduced himself by name Surantani, the messenger of the kingdom Medang Kamulan, while the second player (robber) said his name Sura Dhenta, the messenger of the kingdom Kahuripan.

Motion used in Begalan no specific action guidelines. Motion used are movements of improvisation or spontaneous, monotonous, and seen their own wishes, which is important in accordance with the rhythms. Examples range of motion is a motion Begalan include: walking or lumaksana, sindhetan Banyumasan, geyol, entrakan, and others. Motion used is not patterned sequence and performed repeated.

No accompaniment in the traditional arts that use accompaniment internal, external, and some use to both. On Performing arts of Begalan classified accompaniment accompaniment used externally. Before the rapidly developing technology implemented directly accompaniment, along with the development of technology, no accompaniment accompaniment can be used directly, for example using a cassette and CD.

Performing arts of Begalan cosmetology used includes dressing character as it aims to establish the desired characters. There are two figures in Begalan of the character and the mugger mugged. Overall makeup used on Begalan art is both simple and straightforward both in terms of the materials used, color scheme, as well as how to use it. Makeup used, among others: (1) the powder, sinwit white (instead of powder), (2) an eyebrow pencil, and (3) lipstick. Sinwit and powder used to polish the face to make it look white. Eyebrow pencil is used to reinforce the eyebrows, sideburns, mustache and beard to bring heroic characters. Lipstick is used for lipstick and blush on the face. Overall the makeup is makeup manly types. Hair dressing dancer son left to decompose enough then given iket or blangkon as headgear

Floor pattern used in the presentation of Begalan in Banyumas is a pattern of the floor face to face. The pattern of the floor face to face is used in almost all Begalan presentation. The venue of Begalan usually done in the yard before the bride down the aisle or reception hall. As the times Begalan also often staged in the building, with a position in front of the bride. Begalan lighting art performances staged during the day if only rely on the sun, and when the evening was staged lighting harness the power source using fluorescent lamps as illumination. Before the use of electric lighting Begalan art show at night by utilizing lighting petromaks, senthir, and blencong (Sefiati, 2014) 
In order for the show smoothly staging performances Begalan must consider elements of sound. Supplies sound system equipment is needed in an organization of presentation begalan. Sound system used among others mike is immediately taken by the player begalan. Property performances Begalan be some kitchen utensils. Among the group Begalan one and the other can be different in kind but still property used in performing arts of Begalan among others: Ian, Ilir, Kukusan, Pedaringan, layah or ciri, Muthu, Irus, siwur, Rice, Wangkring, Sapu sada Suket, muthu, cething, Daun Salam, and Tampah. Luggage is usually called brenang kepang. Harrier property in the form of a wooden sword called wlira (Budiastuti, 2015).

\subsection{THE RELIGIOUS VALUES IN BRENANG KEPANG EQUIPMENT}

The kinds of kitchen equipment in brenang kepang consisted some advices, pitutur, dan pitudhuh the bride and groom who married, and the audience at the ceremony. Ian is a square-shaped kitchen appliance and used as a base to cool the rice (angi). Ian made of woven bamboo and clamped on all four sides, but it is bigger than ilir. The general meaning of Ian was for the bride that they should be lived in harmony. (mikrokosmos). Ian is also a symbol of character (do well). Moreover it must work in order to make living without leaving the God (eling).

Ilir is one of kitchen equipment to make the rice cool (angi). The shape of Iliris a square made from woven bamboo, but it is smaller than Ian. The meaning of Ilir was as people live in married life, should not be concerned with their own wishes and had selfish attitude, because it would increase the problems in a family. Additionally, ilir or fan was a symbol of reassuring the life or symbolize that people should not be a provocateur.

Pikulan/wangkringis made rom bamboo and used to carry something heavy in hand. The value that can be taken from the kitchen equipment embatan are mutual cooperation and discussion dealing with a problem in the family. People should not distinguish with another religions and respectful.

Kukusan had meaning that in a marriage life, they had to change the mindset. This is in accordance with the kukusan function; it converts something uncooked to be cooked. The basic guiding, that every married people should think more mature because he had entered a higher stage of life.

Ciri and muthu was the kitchen equipment that used as a tool to make the kitchen spices smooth. This tool also symbolizing the phallus and yoni, the two are inseparable and always united to get delicious flavors (Chusmeru, 2011: 6). The meaning indicated are complementary and help each other.

Cething was the kitchen equipment that used as a rice basket. That a husband or wife should work to make money, saved as much as possible and used it well. Moreover, it has a meaning that people who live in a society should obey some certain rules. Therefore, people should not act as they pleased because he would be responsible for their attitude.

The meaning of centhong was in the marriage living should be able to process a bad situation into a good one and always put discussion and equity.

Tampah was a tool used to select whether the good or bad rice. It symbolized that people should choose the good things and avoids the bad things. Tampahcame from keratabasameansditata men rawutah. Thus were the lesson for a husband to organize and manage his family as the leader of the family.

Siwur was kitchen equipment used to take water made from coconut shell that given a handle. Siwur also known as cidhuk/gayung. Siwur had the meaning that nek wis isi aja diawur-awur. It means that in family living should use everything in accordance with the needs and should not be in awur-awur (extravagant). The implicit meaning conveyed through siwur was saving.

The purpose of Kendhil Pratala and its contents was as a person who married must attempt to work to make living. It was symbolized as coins and rice. People are required to work to collect 
the money to be used wisely. Moreover, Kendhil made from the soil. It was a symbol that human in the future buried. Thus can make people be obedient to the God.

Sorok is a kitchen equipment used for taking something fried. Sorok can be interpreted as aja seneng carak-corok. It means that as a human being, we should not envy and reproach to others.

Sapu lidi or broom had meaning that in a marriage should live in harmony. Broom symbolizes that a marriage life must be united and do not stand alone. The value delivered through the broom is togetherness, unity and integrity (guyub pillar) in building real life.

Pari/rice was the part of usual crops symbolized as Dewi Sri, the Goddess of Fertility, and the Goddess of Prosperity. The philosophy of rice can be concluded that a human should fight, work and study when young and stay humble once their aged.

The study about the equipment used in brenang kepang was one of the studies that used the meaningful signs. This study was as same as the study done by Doina dkk (2012) entitled Specific Cultural Communication through Archaic Signs and Symbols. The research result was a pattern to read the symbols and signs on the specifics cultural communication. The result in the form of a diagram that starts from reading the marker, sign, symbol and then back again to the marker.

\subsection{THE RELIGIOUS VALUE OF BEGALAN BANYUMASAN AS A SOURCE OF THE EDUCATIONAL CHARACTER VALUE IN SCHOOL}

The implementation of Begalan tradition was an activity that leads to the religious value. Based on the description and the meaning of kitchen equipment, the value can be applied into daily life. Brenang kepang contained some meaning, pitutur, and pitudhuh to the bride and groom who married, and the audience at the ceremony. The advice was for the bride to build up their character related with God. It was reflected by their attitude in doing some religious practices. Then, with the religious value taught can made a vertically relationship. It was the relationship between human, associated with mutual respect in the marriage and the environment.

Based on the explanation about kitchen equipment and educational character value, it can be applied to learning process in schools. The educational value of these characters can also be used as a source of education, especially religious values and guidelines for learning in schools. Study by Dwiningrum (2013) produced several factors and underlying social capital and supporting character education of students in the school. These factors included participation and social relationships, beliefs, social norms, social rules, and proactive behavior. Based on these factors, the characteristics of students can be. There were also other elements that support the student's character that is about the educational environment in the family, school and community.

Based on the above description that one of the educational value that is contained in the performing arts of Begalan is ethics education. Ethics education in question is the ethics education or education about good and bad teachings that must be understood by the student to be applied in life in the world of education. Ethics education in the performing arts of Begalan aims to provide learning to students in order to get along in harmony and balance in life in educational environments.

Education ethics contained in the performing arts of Begalan included in group normative ethics for explaining a judgment of good and bad, as well as showing what should be done by the students. Java Ethics outlines submitted in two ways, first through pituduh (advice, recommendation) whose contents give advice in the form of a recommendation. Both through pepali (wewaler) means that the Javanese away from bad deeds. Advice and ban is the core of morality or ethics. The purpose of giving advice and prohibition is unharmed or slamet. Manners or ethics for the Java community is a necessity. Java manners or ethics delivered from a particular party to another party who have not the same position. Java ethics implemented in an effort to keep the harmony of human life (Endraswara, 2003: 37). 


\subsection{CONCLUSSION}

The role of religiosity in Begalan Banyumasan as a character education in schools had an important role. From the order of events, speech, and equipment brought in Begalan had each meaning or religious values. The brenang kepang equipment contained many values of educational character that is relevant to the curriculum and learning process in schools, especially in high school level. Through the high school level, the value of religiosity character education, especially in the traditional ceremony Begalan Banyumasan can be used as a source and tool in teaching and learning activities.

\section{References}

Bahtiar, Muhammad. (2015). Analisis Gaya Bahasa dan Nilai Pendidikan Dalam Serat Wedhtama Pupuh Pangkur Sebagai Bahan Ajar Mata Pelajaran Bahasa Jawa Tingkat SMA (Suatu Kajian Stilistika). Surakarta: UNS.

Budiastuti, E. D. (2015). Persepsi Masyarakat Terhadap Makna Simbolik dan Tinjauan Hukum Islam dalam Tradisi Begalan di Desa Karangsalam Kecamatan Kemranjen Kabupaten Banyumas. ADITYA-Pendidikan Bahasa dan Sastra Jawa, 6(2), 63-71.

Endraswara, S. (2003). Budi Pekerti dalam Masyarakat Jawa. Yogyakarta: Hanindita.

Herusatoto, B. (2008). Banyumas: Sejarah, Budaya, Bahasa, dan Watak. Yogyakarta: LKiS Pelangi Aksara.

Hosang, Nooke. (2010). Tradisi Perkawinan Jepang. (Interlingua Vol 4, April 2010.)

Ishak, M. T., Mochsen, M. S. (2005). "Pembacaan Kode Semiotika Rolan Barthes terhadap Bangunan Arsitektur Katedral Evry di Prancis Karya Mario Botta." Rona Jurnal Arsitektur FT Unhas. 2(1), $85-92$.

Kasyfiyullah. (2011). "Etnography on Etnography; Etnografi Anak-anak (Studi Etnografi terhadap Proses Etnografi Sekolah)." Forum Ilmiah. 8(3), 246-257.

Kuswarno,E. (2008).Etnografi Komunikasi. Bandung: Widya Padjadjaran.

Lestari, P. (2013). "Symbolic Meanings of Begalan for Learning Ethics for Society." Harmonia: Journal of Arts Research and Education, 13(2), 157-167

Mustari, Muhamad. (2014). Nilai Karakter Refleksi Untuk Pendidikan. Jakarta: PT Raja Grafindo Persada.

Putra, S. H. A. (2006). Strukturalisme Levi-Strauss Mitos dan Karya Sastra. Yogyakarta: Kepel Press.

Sefianti, L. (2014). "Tradisi Begalan di Desa Karangmangu Kecamatan Kroya Kabupaten Cilacap." ADITYA-Pendidikan Bahasa dan Sastra Jawa, 5(1), 63-70.

Selian, Rida S.(2007). Analisis Semiotik: Upacara Perkawinan "Ngerje" Kajian Estetika Tradisional Suku Gayo di Dataran Tinggi Gayo Kabupaten Aceh Tengah. Semarang: UNNES.

Setyobudi, I. (2009). Etnografi dan Genre Sastra Realisme Sosialis. Asintya. 1(2), 109-118.

Spradley. J. P. (2007). Metode Etnografi. Yogyakarta: Tiara Wacana.

Suhartono, S. (2008). Filsafat Pendidikan. Yogyakarta: Ar-Ruzz Media.

Sutopo, H.B. (2006). Metodologi Penelitian Kualitatif. Surakarta: Universitas Sebelas Maret Press.

Wibowo, A. (2013). Pendidikan Karakter Berbasis Sastra. Yogyakarta: Pustaka Pelajar.

Yusmanto, (2015). "Begalan, Tutur Sepuh yang Nyaris Terlupakan.” Makalah disampaikan pada acara Sosialisasi dan Penayangan Film Dokumenter di Kabupaten Banyumas. Balai Pelestarian Nilai Budaya Yogyakarta, Purwokerto, pada tanggal 9 Juni 2015. 